\title{
THERMODYNAMIC PROPERTIES OF WATER ADSORPTION FROM ORANGE PEELS
}

\section{PROPRIEDADES TERMODINÂMICAS DE ADSORÇÃO DA ÁGUA DE CASCA DE LARANJA}

\author{
Harvey Alexander VILLA-VÉLEZ ${ }^{[1]}$, Silvio José Ferreira de SOUZA ${ }^{[1]}$; Augusto Pumacaua RAMOS ${ }^{[1]}$; Tiago \\ POLACHINI and Javier TELIS-ROMERO ${ }^{[1]}$ \\ [1] São Paulo State University (UNESP). 2265 St. Cristóvão Colombo - Jardim Nazareth, CEP 15054-000, São José do Rio Preto - SP, Brazil. \\ siljo@ibilce.unesp.br; javier@ibilce.unesp.br; pumacaua@hotmail.com; tiagopolachini@terra.com.br;
}

*Corresponding author: harveyvilla@gmail.com

\begin{tabular}{|c|c|}
\hline ARTICLE INF. & ABSTRACT \\
\hline & \multirow{11}{*}{$\begin{array}{l}\text { Orange peels are a promising agroindustry-waste that can be implemented in the } \\
\text { extraction and production of pectin, as dietary fiber in food formulations, and as a } \\
\text { biopolymer for metal adsorption in water treatment. The present work, therefore, aims } \\
\text { to study the adsorption isotherms and the thermodynamic properties of the water } \\
\text { adsorbed from orange peels ( } C \text {. sinensis cv. Brazilians) at six different temperatures ( } 20 \text {, } \\
30,40,50,60 \text { and } 70{ }^{\circ} \mathrm{C} \text { ) in the water activity range of } 0.020 \text { to } 0.853 \text {. The GAB model was } \\
\text { applied in modeling the experimental adsorption isotherms of orange peels, obtaining } \\
\text { statistical values of } R^{2}=0.996 \text {. Differential and integral thermodynamic properties of } \\
\text { water sorption for orange peels were determined by the analytical derivation of the water } \\
\text { activity with respect to the temperature from GAB model. Results of the differential } \\
\text { thermodynamic properties showed an energetic interaction zone of water molecules with } \\
\text { the material. Furthermore, integral thermodynamic properties showed an equilibrium } \\
\text { zone controlled by the orange peel enthalpy and entropy. Finally, the orange peel power } \\
\text { adsorption information can be used as a point of reference for the controlled process in } \\
\text { the different application areas. }\end{array}$} \\
\hline Accepted: 05/18/2015 & \\
\hline Published: 06/05/2015 & \\
\hline Document Object Identifier & \\
\hline 10.18607/jbfs.v2i2.32 & \\
\hline Editor: V. H. G. Sales & \\
\hline jbfs@ifap.edu.br & \\
\hline ID JBFSO322015 & \\
\hline Double blind peer review & \\
\hline & \\
\hline Prot. $0322015 R 02$ & \\
\hline
\end{tabular}

Copyright: (C) 2015

JBFS all rights (BY NC SA)

Keywords: agro-waste, analytical derivation, GAB model, modeling, water content

RESUMO - As cascas de laranja são resíduos importantes da agroindústria que podem ser empregados na extração e produção de pectina, produção de fibra, em formulações de alimentos e como um biopolímero em processos de adsorção de metais no tratamento de águas. Assim, o objetivo deste trabalho foi estudar as isotermas de adsorção de casca de laranja (Citrus sinensis cv. Brasileira) a seis diferentes temperaturas $\left(20,30,40,50,60\right.$ e $70^{\circ} \mathrm{C}$ ) na faixa de atividade de agua de 0.020 até 0.853 . Para isto, o modelo teórico de GAB foi usado para modelar as isotermas experimentais de adsorção da casca de laranja, mostrando valores estadísticos de $R^{2}=0.996$. Propriedades termodinâmicas diferenciais e integrais de sorção da água na casca de laranja foram determinadas através da derivada analítica da atividade de água com respeito à temperatura proveniente do modelo de GAB. Os resultados das propriedades termodinâmicas diferenciais mostraram uma área de interação energética das moléculas de água com o material. Além disso, as propriedades termodinâmicas integrais mostraram uma área de equilíbrio controlado pela entalpia e entropia para a casca de laranja. Finalmente, a informação sobre o poder de adsorção de casca de laranja pode ser usada como ponto de referência no controle de processos para as diferentes áreas de aplicação.

Palavras-chave: agroresíduos; derivação analítica; modelo de GAB; modelagem; conteúdo de água.

Funding: The authors report support and funding in the work done by the CNPq (National Council for Scientific and Technological Development), Brazil. The funder had no role in study design, data collection and analysis, decision to publish, or preparation of the manuscript.

Competing interests: The authors have declared that no competing interests exist.

How to refer to this document (ABNT):

VILLA-VÉLEZ, H. A.; SOUZA, S. J. F. de; RAMOS, A. P.; POLACHINI, T.; TELIS-ROMERO, J. Thermodynamic properties of water adsorption of orange peel. Journal of Bioenergy and Food Science, Macapá, v.2, n.2, p.72-81, abr./jun.. 2015. DOI 10.18607/jbfs.v2i2.32 


\section{INTRODUCTION}

Orange is the most important citrus fruit, with a global production (2014/2015) estimated at 1.8 million tons, with Brazil, USA and Mexico being the largest producer, processer and exporter countries in the world (USDA, 2015). The fruit is a hesperidium, with carpels, or segments filled with juicy arils and seeds (DOIJODE, 2001). The peel includes the epidermis covering the exocarp consisting of irregular parenchymatous cells which completely enclose numerous glands or oil sacs (LIN et al., 2010). It is a rich source of essential oils, cellulose, pectin (galacturonic acid), hemicellulose and lignin, commonly used in diverse industries (VELÁZQUEZNUÑEZ et al., 2013; FENG \& GOU, 2012; REZZADORI et al., 2012). Due to the interest of the potential use of orange by-products in industrial sources, the application of preservation technologies for this organic material is needed to avoid degradative reactions, such as oxidation or microbial spoilage. Among the different preserving technologies used, drying is the most common in food industry (GARAU et al., 2007; GARCíA et al., 2008).

The final degree of stability reached by drying is not only dependent on the moisture content but also on the product sorption properties (LABUZA et al., 1985). The thermodynamics of water sorption in dried foods have drawn interest because for providing a more thorough interpretation of the sorption isotherm phenomenon, helping to better understand the sorption mechanism (AL-MUHTASEB et al., 2002; RIZVI, 2005). Thermodynamic properties, such as enthalpy, entropy and Gibbs free energy are essential to represent and describe the reactions and phenomena that occur at intermolecular level in materials (BROVCHENKO \& OLEINIKOVA, 2008).

Sorption isotherms are useful to model changes in water content and to calculate the thermodynamic parameters (RIZVI, 2005; WILHELM et al., 2011). Many models have been proposed in the literature, and it is interesting to check how well some of them fit to sorption isotherms. The GAB model is among the most commonly used models, with the ability to predict the moisture content during storage under a wide variety of conditions, and the parameters can be related with the energetic state of the water molecules in the sorption monolayer and multilayer (SIMAL et al., 2007; EIM et al., 2011; VILLA-VÉLEZ et al., 2012).

With this, the aim of this work was to provide data on experimental adsorption isotherms of orange peels at several temperatures, to test the

J. Bioen. Food Sci., v. 2, n.2: p.39-45, 2015 feasibility of the GAB model and to assess some thermodynamic properties of water sorption.

\section{MATERIALS AND METHODS}

Raw material and sample preparation

Fresh oranges ( $C$. sinensis cv. Brazilians) were picked in an advanced stage of ripeness in São José do Rio Preto city (São Paulo, Brazil). The whole oranges were washed, strained with blotting paper and stored at $4{ }^{\circ} \mathrm{C}$ until processing. The seeds and peel reached $33 \pm 1 \%$ of the total weight of the orange, with the albedo being $46.4 \%$ and the flavedo $53.6 \%$ of the total peel weight. The average thickness of the peel was $7.3 \pm 1.2 \mathrm{~mm}$. The initial moisture content of the orange peel was $5.671 \mathrm{~kg}$ water/kg dry solid), determined by a vacuum oven according to the AOAC method 934.06 (AOAC, 1997).

The orange peels were separated from the pulp by hand and slightly ground using a kitchen houseware apparatus. Ground samples were dried in a thin layer of $1 \mathrm{~cm}$ at $40{ }^{\circ} \mathrm{C}$ using an air forced convective drier at $2.0 \mathrm{~m} / \mathrm{s}$ for $10 \mathrm{~h}$, until a constant weight was reached. The sample layer was manually stirred during the drying period to achieve homogenous moisture content. The dried sample was kept in closed storage jars for posterior experimentation.

\section{Sorption isotherms}

The equilibrium moisture content of the orange peels was determined using the static gravimetric method (JOWITT et al., 1987) at temperatures from 20 to $70{ }^{\circ} \mathrm{C}$. The experimental setup consisted of eight hermetic glass jars containing different saturated salt solutions, corresponding to values of relative humidity $(\mathrm{RH})$ from 2.0 to $85.3 \%$. Each jar was filled to a depth of $1.5 \mathrm{~cm}$ with the appropriate salt solution. Three small plastic containers containing the dry sample (1 g) were placed in the jars, thus, three replicates of the same experiment were carried out. Afterwards, the jars were placed in a temperature-controlled chamber, model TE-391 (Tecnal, Piracicaba, Brazil), under different temperatures. The weight of the samples was measured until the moisture content did not exceed $0.1 \%$ (dry weight basis) (time elapsed-from 4 to 5 weeks). At that point, equilibrium was assumed to be reached, thus ensuring that the water activity of each sample corresponded to the relative humidity fixed by the salt. For each sample, the initial moisture content was determined by a vacuum oven to determine the 
equilibrium moisture content from the registered weight up to equilibrium. The values obtained for the equilibrium moisture content, water activities, and temperatures were used to construct the adsorption isotherms for the orange peels.

\section{Modeling of sorption isotherms}

Adsorption isotherms of orange peels were simulated using the Guggenheim-Anderson-de Boer (GAB) theoretical model (Eq. (1)) as a function of both temperature and water activity (LABUZA et al., 1985).

$$
X=\frac{X_{m} C_{G} K_{G} a_{w}}{\left(1-K_{G} a_{w}\right)\left(1+\left(C_{G}-1\right) K_{G} a_{w}\right)}
$$

Where:

$\boldsymbol{X}$ - is the equilibrium moisture content $(\mathrm{kg} / \mathrm{kg}$, d.b.) $\boldsymbol{a}_{w}$ - the water activity (dimensionless)

$\boldsymbol{x}_{\boldsymbol{m}}$ - the monolayer average equilibrium moisture content $(\mathrm{kg} / \mathrm{kg}$, d.b.)

$\boldsymbol{C}_{\boldsymbol{G}}$ and $\boldsymbol{K}_{\boldsymbol{G}}$ - the GAB model constants (dimensionless).

In Eq. (1), $C_{G}$ and $K_{G}$ constants can be written as function of temperature according to Eqs. (2) and (3), respectively:

$$
\begin{gathered}
C_{G}=C_{0} \exp \left(\frac{H_{m}-H_{n}}{R T}\right) \\
K_{G}=K_{0} \exp \left(\frac{\lambda-H_{n}}{R T}\right)
\end{gathered}
$$

Where:

$\boldsymbol{C}_{0}$ and $\boldsymbol{K}_{\boldsymbol{0}}$ - are GAB model parameters (dimensionless)

$\boldsymbol{H}_{\boldsymbol{m}}$ and $\boldsymbol{H}_{\boldsymbol{n}}$ - are the water sorption heats of the monolayer and multilayer $(\mathrm{kJ} / \mathrm{mol})$, respectively.

$\lambda$ - is the vaporization energy of pure water $(\mathrm{kJ} / \mathrm{mol})$, estimated according to the ASAE Standard Method D271.2DEC99 (ASAE, 1998)

$T$ - is the absolute temperature $(\mathrm{K})$ and

$R$ is the ideal gas constant $(8.314 \mathrm{~kJ} / \mathrm{kmol} \mathrm{K})(\mathrm{RIZVI}$, 2005).

GAB parameters $\left(X_{m^{\prime}}, C_{0^{\prime}} K_{0^{\prime}} H_{m^{\prime}} H_{n}\right)$ were estimated by fitting the equation to the experimental data using the "nlinfit" function of the Statistic Toolbox of Matlab ${ }^{\circledR} 7.1$ (MathWorks Inc., Natick, MA, USA) and considering the "robust" fitting option. The $95 \%$ confidence intervals of the estimated theoretical and empirical parameters were determined by using the "nlparci" function of the same Matlab Toolbox. The coefficient of determination $\left(R^{2}\right)$ (Eq. (4)) and the root mean square error (RMSE) (Eq. (5)) were used to assess the model accuracy (VILLA-VÉLEZ et al., 2012).

$$
\begin{aligned}
& R^{2}=\frac{\sum_{i=1}^{N}\left(X_{i}^{*}-\bar{X}\right)^{2}}{\sum_{i=1}^{N}\left(X_{i}-\bar{X}\right)^{2}} \\
& R M S E=\left[\frac{1}{N} \sum_{i=1}^{N}\left(X_{i}-X_{i}^{*}\right)^{2}\right]^{1 / 2}
\end{aligned}
$$

In Eqs. (4) and (5), $X$ represents the experimental values; $X^{*}$ represents the estimated values; $\bar{X}$ is the average of the experimental values, and $N$ is the number of experimental values.

Differential thermodynamic properties of water sorption

The differential enthalpy $\left(\Delta H_{\text {diff }}, \mathrm{kJ} / \mathrm{mol}\right)$ or net isosteric heat of sorption, determined from the Clausius-Clayperon equation (Eq. (6)) can be linked to the extent of binding between water and solid food particles, which is quite important in calculating the amount of energy needed during hydration (VIGANÓ et al., 2012; DOMÍNGUEZ et al., 2007). For their calculation, was used the quadratic arrangement of GAB model (Eq. (7)) to derive the $a_{w}$ with respect to the temperature (Eq. (8)) as described by Rizvi (2005) and Villa-Vélez et al. (2012).

$$
\begin{aligned}
& \Delta H_{\text {diff }}=-R \frac{\partial\left(\ln a_{w}\right)}{\partial(1 / T)}=\frac{R T^{2}}{a_{w}} \frac{\partial a_{w}}{\partial T} \\
& \alpha=\left(C_{G}-1\right) K_{G}^{2} ; \beta=\left[2-C_{G}\left(1-\frac{X_{m}}{X}\right)\right] K_{G} \\
& \frac{\partial a_{w}}{\partial T}=\frac{\left(\beta a_{w}-1\right) \frac{d \alpha}{d T}-\alpha a_{w} \frac{d \beta}{d T}}{\alpha\left(2 \alpha a_{w}+\beta\right)}
\end{aligned}
$$

The differential entropy $\left(\Delta S_{\text {diff }}\right)$ was obtained from Eq. (9) (HILL et al., 1951).

$\ln a_{w}=-\frac{\Delta H_{\text {diff }}}{R T}-\frac{\Delta S_{\text {diff }}}{R}$

Where:

$\Delta S_{\text {diff }}$ is the molar differential entropy of water adsorbed in the solid $(\mathrm{kJ} / \mathrm{mol} \mathrm{K})$. For both thermodynamic properties $\Delta H_{\text {diff }}$ and $\Delta S_{\text {diff }}$ calculations were carried out estimating the 
properties at the maximum and minimum temperature levels, 20 and $70{ }^{\circ} \mathrm{C}$ respectively (CANO-HIGUITA et al., 2013; VILLA-VÉLEZ et al., 2012).

The free energy of Gibbs $(\Delta G, \mathrm{~kJ} / \mathrm{mol})$ that has an indicative of the estate of the water sorption reaction in the system, was calculated by Eq. (10) (RIZVI, 2005):

$$
\Delta G=R T \ln a_{w}
$$

$\Delta G$ is employed to interpret the linear relationship between the enthalpy and entropy. Changes in $\Delta G$ values provides a criterion to evaluate if water adsorption is a spontaneous $(\Delta G<0)$ or nonspontaneous process $(\Delta G>0)$ (KRUG et al., 1976a; KRUG et al., 1976b).

Integral thermodynamic properties of water sorption

The integral properties were determined through the derivation of first law of thermodynamics (RIZVI, 2005). The net integral heat (enthalpy) of sorption, which indicates the binding strength of water molecules to food particles, can be estimated using the Eq. (11):

$\left[\frac{\partial \ln \left(a_{w}\right)}{\partial(1 / T)}\right]_{\pi}=\frac{\Delta H_{i n t}}{R}$

In Eq. (11) $\Delta H_{i n t}$ is the molar equilibrium enthalpy of sorption or integral enthalpy $(\mathrm{J} / \mathrm{mol})$ at constant potential surface (diffusion pressure or spreading pressure) defined by Eq. (12) (MCMINN et al., 2005):

$\pi=\frac{k T}{A_{m}} \int_{0}^{a_{w}} \frac{X}{a_{w}} d a_{w}$
Where:

$k$ is the Boltzmann's constant $\left(1.380 \times 10^{-23} \mathrm{~J} / \mathrm{K}\right)$

$A_{m}$ is the area of water molecule $\left(1.06 \times 10^{-19} \mathrm{~m}^{2}\right)$ and

$\pi$ the spreading pressure $\left(\mathrm{J} / \mathrm{m}^{2}\right)$ (NEZBEDA \& WEINGERL, 2001).

The compute values of $\pi$ were carried by optimization from the calculated equilibrium moisture content with $G A B$ model in the range of water activity for the different temperatures.

Once, $\Delta H_{\text {int }}$ is obtained, the changes in the molar integral entropy can be calculated using Eq. (13):

$\Delta S_{i n t}=\frac{-\Delta H_{i n t}-R T \ln a_{w}}{T}$

Where:

$\Delta S_{\text {int }}$ is the integral entropy of water adsorbed in the food (J/mol K) (MAJD et al., 2012).

Similar to the differential thermodynamic properties, the integral properties $\left(\Delta H_{i n t}\right.$ and $\left.\Delta S_{\text {int }}\right)$ were calculated at the maximum and minimum temperature levels, 20 and $70{ }^{\circ} \mathrm{C}$ respectively.

\section{RESULTS AND DISCUSSION}

Experimental sorption isotherms

Experimental equilibrium moisture content data $(X, \mathrm{~kg} / \mathrm{kg}, \quad$ d.b. $)$ of orange peels were determined using a statically gravimetric method at six temperatures levels $\left(20,30,40,50,60\right.$ and $\left.70^{\circ} \mathrm{C}\right)$ in the water activity range of $0.200-0.853$. Table 1 shows the experimental results for the equilibrium moisture content.

Table 1. Experimental equilibrium moisture contents for the orange peel* at temperatures ranging from 20 to 70 ㅇ.

\begin{tabular}{ccccccccc}
\hline$T\left({ }^{\circ} \mathrm{C}\right)$ & $a_{w}$ & $X(\mathrm{~kg} / \mathrm{kg}, \mathrm{d} . \mathrm{b})$. & $T\left({ }^{\circ} \mathrm{C}\right)$ & $a_{w}$ & $X(\mathrm{~kg} / \mathrm{kg}, \mathrm{d} . \mathrm{b})$. & $T\left({ }^{\circ} \mathrm{C}\right)$ & $a_{w}$ & $X(\mathrm{~kg} / \mathrm{kg}, \mathrm{d} . \mathrm{b})$. \\
\hline \multirow{6}{*}{20} & 0.070 & $0.016 \pm 0.001$ & & 0.069 & $0.015 \pm 0.001$ & & 0.045 & $0.010 \pm 0.001$ \\
& 0.113 & $0.025 \pm 0.001$ & & 0.112 & $0.023 \pm 0.000$ & & 0.110 & $0.025 \pm 0.000$ \\
& 0.246 & $0.051 \pm 0.002$ & & 0.223 & $0.049 \pm 0.001$ & & 0.175 & $0.036 \pm 0.001$ \\
& 0.331 & $0.068 \pm 0.001$ & & 0.324 & $0.064 \pm 0.002$ & & 0.307 & $0.063 \pm 0.001$ \\
& 0.446 & $0.097 \pm 0.001$ & 30 & 0.439 & $0.093 \pm 0.001$ & 60 & 0.432 & $0.097 \pm 0.001$ \\
& 0.547 & $0.135 \pm 0.005$ & & 0.526 & $0.117 \pm 0.002$ & & 0.473 & $0.105 \pm 0.001$ \\
& 0.655 & $0.202 \pm 0.002$ & & 0.635 & $0.191 \pm 0.002$ & & 0.590 & $0.157 \pm 0.001$ \\
& 0.754 & $0.353 \pm 0.004$ & & 0.756 & $0.342 \pm 0.002$ & & 0.740 & $0.320 \pm 0.002$ \\
& 0.853 & $0.965 \pm 0.027$ & & 0.835 & $0.676 \pm 0.006$ & & 0.800 & $0.496 \pm 0.013$ \\
\hline
\end{tabular}

"To be continued" 
Table 1. Conclusion

\begin{tabular}{ccccccccc}
\hline$T\left({ }^{\circ} \mathrm{C}\right)$ & $a_{w}$ & $X(\mathrm{~kg} / \mathrm{kg}, \mathrm{d} . \mathrm{b})$. & $T\left({ }^{\circ} \mathrm{C}\right)$ & $a_{w}$ & $X(\mathrm{~kg} / \mathrm{kg}, \mathrm{d} . \mathrm{b})$. & $T\left({ }^{\circ} \mathrm{C}\right)$ & $a_{w}$ & $X(\mathrm{~kg} / \mathrm{kg}, \mathrm{d} . \mathrm{b})$. \\
\hline \multirow{6}{*}{40} & 0.066 & $0.015 \pm 0.001$ & & 0.059 & $0.015 \pm 0.000$ & & 0.020 & $0.005 \pm 0.000$ \\
& 0.111 & $0.024 \pm 0.000$ & & 0.110 & $0.023 \pm 0.000$ & & 0.110 & $0.024 \pm 0.001$ \\
& 0.206 & $0.044 \pm 0.001$ & & 0.189 & $0.038 \pm 0.000$ & & 0.162 & $0.034 \pm 0.000$ \\
& 0.319 & $0.066 \pm 0.002$ & & 0.314 & $0.060 \pm 0.001$ & & 0.294 & $0.062 \pm 0.000$ \\
& 0.432 & $0.095 \pm 0.002$ & 50 & 0.432 & $0.095 \pm 0.001$ & 70 & 0.432 & $0.093 \pm 0.001$ \\
& 0.506 & $0.115 \pm 0.001$ & & 0.489 & $0.111 \pm 0.001$ & & 0.458 & $0.100 \pm 0.001$ \\
& 0.615 & $0.178 \pm 0.001$ & & 0.599 & $0.166 \pm 0.001$ & & 0.587 & $0.157 \pm 0.002$ \\
& 0.753 & $0.351 \pm 0.001$ & & 0.746 & $0.329 \pm 0.000$ & & 0.739 & $0.319 \pm 0.002$ \\
& 0.820 & $0.599 \pm 0.003$ & & 0.809 & $0.540 \pm 0.008$ & & 0.795 & $0.461 \pm 0.011$ \\
\hline
\end{tabular}

Mean and standard deviation for three replicates; $X$ : experimental equilibrium moisture content; $a_{w}$ : water activity (dimensionless).

In Table 1, values for $X$ ranged from $0.005-$ $0.965 \mathrm{~kg} / \mathrm{kg}$, d.b., being observed a "slight" increase of $X$ when water activity increases for each level of temperature, whereas was not found a significant difference of $X$ when increases the temperature for each level of water activity. Similar results were showed by Bejar et al. (2012) for adsorption isotherms of orange peel (variety Maltaise) in the temperature range of $40-60{ }^{\circ} \mathrm{C}$. These "unusual" results can be attributed to the characteristic of products holding small amounts of water at low water activity $\left(a_{w}\right)$ levels and large amounts at high relative humidity. Behavior changes of peel during adsorption could be due to the richness of these byproducts in sugars, protein and fiber and to modification of water molecules adherence to these components. This behavior can be linked to the drying process applied in sample preparation. According to Garau et al. (2007) at temperatures of 60 and $70{ }^{\circ} \mathrm{C}$, the drying kinetics of orange peel showed a meaningful case-hardening phenomenon. This effect hinders in certain way the release and the adsorption of water in the material, explaining the slow water adsorption at low water activities. Other reliable explications can be linked to the fact that orange peel contains a hydrophobic surface "flavedo" (RAEISSI et al., 2008; GHANEM et al., 2012), where the oils sacs contained in this region play a key role as waterproofing and, a surface with high sugar content "albedo" (FOO \& HAMEED, 2012; GUPTA \& NAYAK, 2012) that at high temperatures reduce the sites of water sorption in the material.

Modeling of sorption isotherms by $\mathrm{GAB}$ equation

The theoretical GAB model was fitted to the experimental sorption isotherms of orange peel, showing a statistical performance of $R^{2}=0.996$ and $R M S E=0.011$. Graphical and parameter results of GAB model are shown in Figure $\mathbf{1}$ and Table 2, respectively. In Figure $\mathbf{1}$, it can be observed exponential-closed curves that according with Brunauer et al. (1940), they can be cataloged as type III, characteristic of products with high sugar content.

A similar behavior was observed in agrowastes such as jackfruit peels (PRETTE et al., 2013), banana peels (VILLA-VÉLEZ et al., 2012) and lemon peels (GARCÍA-PÉREZ et al., 2008) at temperatures ranging from 20 to $70^{\circ} \mathrm{C}$.

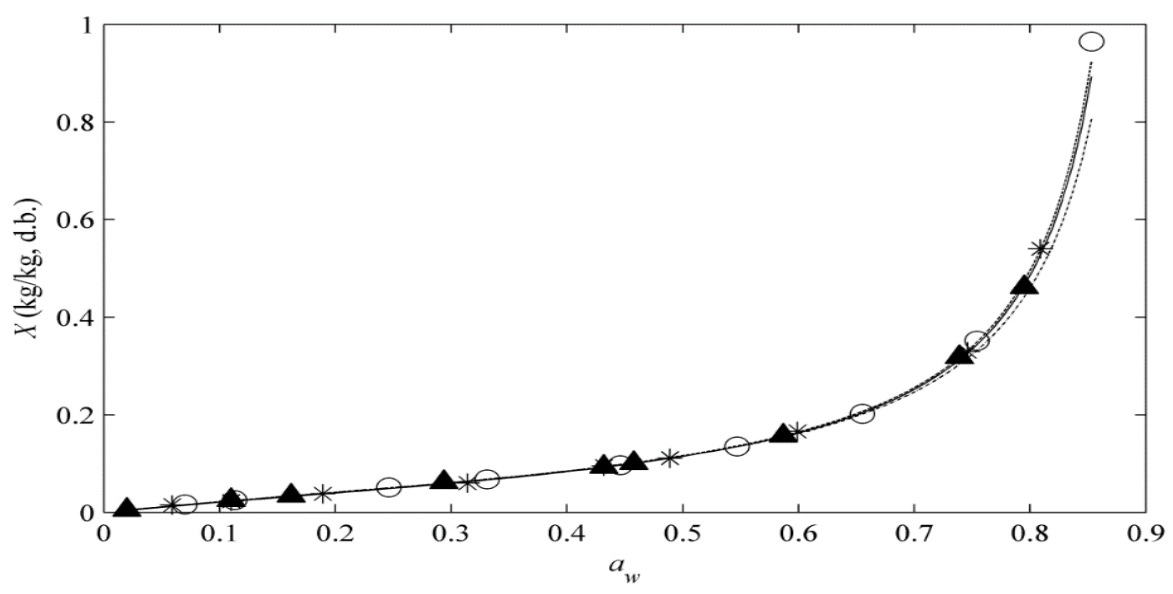

Figure 1. Experimental and calculated values using the $G A B$ model (-) for the adsorption isotherms of orange peel at temperatures of $20^{\circ} \mathrm{C}(0), 50{ }^{\circ} \mathrm{C}(*)$ and $70^{\circ} \mathrm{C}(\boldsymbol{\Delta})$. 
Table 2. Estimated GAB model parameters and statistical results.

\begin{tabular}{|c|c|c|c|c|c|}
\hline Parameters & Units & Value & $95 \%$ confidence intervals & $R^{2}$ & RMSE \\
\hline$X_{m}$ & $\mathrm{~kg} / \mathrm{kg}$, d.b. & $6.602 \times 10^{-2}$ & $6.369 \times 10^{-2}-6.835 \times 10^{-2}$ & & \\
\hline$C_{0}$ & dimensionless & 5.879 & $-3.277-15.036$ & & \\
\hline$K_{0}$ & dimensionless & 195.700 & $190.340-201.070$ & 0.996 & 0.011 \\
\hline$H_{m}$ & $\mathrm{~kJ} / \mathrm{mol}$ & 55.411 & $51.248-59.576$ & & \\
\hline$H_{n}$ & $\mathrm{~kJ} / \mathrm{mol}$ & 56.844 & $56.781-56.907$ & & \\
\hline
\end{tabular}

$X_{m}$ : monolayer average equilibrium moisture content; $C_{0}$ and $K_{0}:$ GAB model parameters; $H_{m}:$ monolayer sorption heat; $H_{n}$ : multilayer sorption heat.

In Table 2, the value of the average equilibrium moisture of the monolayer provides information on the amount of water which is strongly adsorbed to active sites on the food surface and which is also related to food stability. The results showed an $X_{m}$ value of $6.6 \times 10^{-2} \mathrm{~kg} / \mathrm{kg}$, d.b. close to other products such as banana peels $6.6 \times 10^{-2} \mathrm{~kg} / \mathrm{kg}$, d.b. (VILLA-VÉLEZ et al., 2012), jackfruit peels 3.5×10${ }^{2} \mathrm{~kg} / \mathrm{kg}$, d.b. (PRETTE et al., 2013) and lemon peels from $6.4 \times 10^{-2}-4.9 \times 10^{-2} \mathrm{~kg} / \mathrm{kg}$, d.b. (GARCÍA-PÉREZ et al., 2008). For this study, the $X_{m}$ parameter was nearly constant for all temperatures, it represents the minimum water content covering hydrophilic sites on the material surface, providing important information on physical and chemical stability of dehydrated products with regard to lipid oxidation, enzyme activity, non-enzymatic browning, flavor component preservation and structural characteristics (MRAD et al., 2012). Values of $C_{G}$ and $K_{G}$ calculated through the parameters in Table 2 from the GAB model (Eq. (1)) show low variation with temperature, as shown in Table 3. For orange peels, the values of the constant $K_{G}$ were close to one, results that indicate that there was a difference in free enthalpy between the sorbate molecules in the pure liquid and those in the second sorption stage in the layer above the monolayer (GABAS et al., 2007; EIM et al., 2011; MULET et al., 2002).

Table 3. Estimated $C_{G}$ and $K_{G}$ parameters from GAB model at temperatures ranging from 20 to $70^{\circ} \mathrm{C}$.

\begin{tabular}{cccc}
\hline$T\left({ }^{\circ} \mathrm{C}\right)$ & $C_{G}$ & $K_{G}$ & $R M S E$ \\
\hline 20 & 3.266 & 1.087 & 0.092 \\
30 & 3.330 & 1.088 & 0.066 \\
40 & 3.391 & 1.089 & 0.050 \\
50 & 3.449 & 1.090 & 0.046 \\
60 & 3.505 & 1.091 & 0.038 \\
70 & 3.558 & 1.092 & 0.058 \\
\hline
\end{tabular}

$C_{G}$ and $K_{G}: G A B$ model parameters (dimensionless)

Moreover, the estimated heat of sorption of the monolayer $\left(H_{m}\right)$ was $55.41 \mathrm{~kJ} / \mathrm{mol}$ for orange peels (using the estimated values of the heat vaporization of pure water $(\lambda)$ from $44.2-42.0$ $\mathrm{kJ} / \mathrm{mol}$, corresponding to the temperature range of $20-70^{\circ} \mathrm{C}$ ). These values were close to other agrowastes, such as banana peels, $H_{m}=35.56 \mathrm{~kJ} / \mathrm{mol}$ (VILLA-VÉLEZ et al., 2012) and lemon peels, $H_{m}=43.0$ $\mathrm{kJ} / \mathrm{mol}$ (GARCÍA-PÉREZ et al., 2008). For the estimated heat of sorption of the multilayer $\left(H_{n}\right)$, a value of $56.84 \mathrm{~kJ} / \mathrm{mol}$ was found. $H_{m}$ and $H_{n}$ figures were very close, which is consistent with the theory suggesting that the state of the sorbate molecules in the second and higher layers is equal, but different from that in the liquid-like state (AL-MUHTASEB et al., 2002). The relationship $\left(H_{m}-H_{n}\right)$ was negative, indicating a strong endothermic interaction of water vapor with primary sorption sites of the orange peels (RIZVI, 2005).

Differential thermodynamic properties of water sorption

The differential enthalpy $\left(\Delta H_{\text {diff }}\right)$ of water sorption of orange peel was computed by the Clausius-Clapeyron Eq. (6). $\Delta H_{\text {diff }}$ was computed at temperatures of 20 and $70 \stackrel{\circ}{ } \mathrm{C}$ and equilibrium moisture contents up to $0.400 \mathrm{~kg} / \mathrm{kg}$, d.b., such as showed in Figure $2 \boldsymbol{a}$.

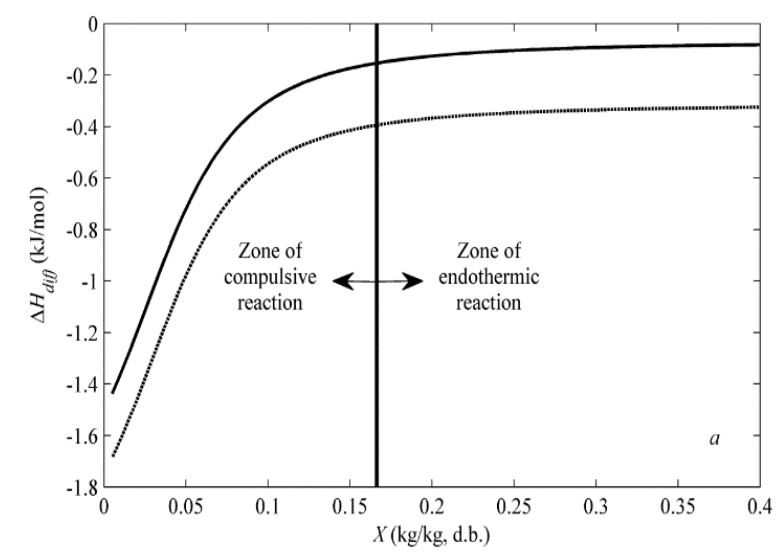



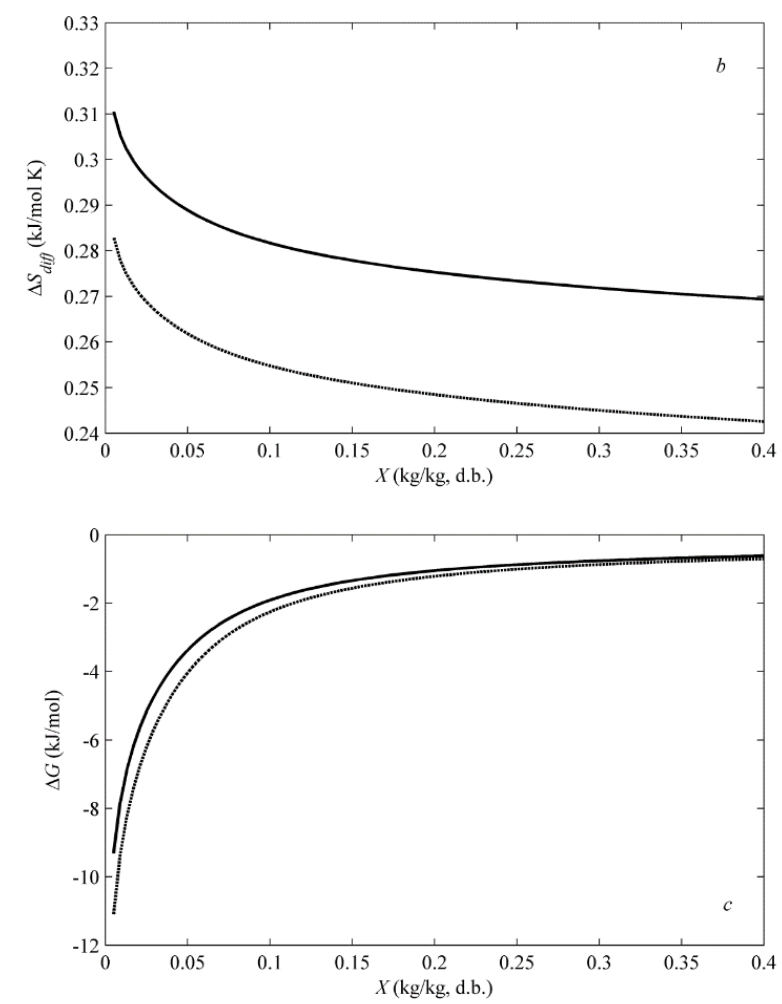

Figure 2. Differential enthalpy $(a)$, differential entropy $(b)$ and Gibbs free energy $(c)$ of water sorption for orange peel at $20{ }^{\circ} \mathrm{C}(-)$ and $70{ }^{\circ} \mathrm{C}(--)$, as a function of the moisture content.

In Figure $2 a$, values of $\Delta H_{\text {diff }}$ in the region of $X<0.17 \mathrm{~kg} / \mathrm{kg}$, d.b. showed a smaller order of magnitude than the constant region presented for the temperatures 20 and $70 \stackrel{\circ}{ } \mathrm{C}$, in the region of $x>0.17 \mathrm{~kg} / \mathrm{kg}$, d.b. The same tendency was also showed by Tsami (1991), suggesting the formation of a zone of compulsive reaction. The more negative the value of $\Delta H_{\text {diff' }}$, the higher the degree of binding of water on the food surface. In the zone of compulsive reaction, the solubilization of sugars should be low due to the plasticization of the surface of orange peels, probably occurred during drying, which may hinder the water adsorption in the material (ROMAN et al., 1982). Values of $\Delta H_{\text {diff }}$ above of $X>0.17 \mathrm{~kg} / \mathrm{kg}$, d.b. showed an endothermic reaction, attributed to the concentration of sugars in the material. For both temperatures, $\Delta H_{\text {diff }}$ is smaller than the heat of vaporization of pure water (TSAMI, 1991).

The differential entropy $\left(\Delta S_{\text {diff' }}, \mathrm{kJ} / \mathrm{mol} \mathrm{K}\right)$ shown in Figure $\mathbf{2} \mathbf{b}$ was calculated as a function of the moisture content at temperatures of 20 and 70 ${ }^{\circ} \mathrm{C}$. $\Delta S_{\text {diff }}$ decreased from 0.31 to $0.26 \mathrm{~kJ} / \mathrm{mol} \mathrm{K}$ at 20 ${ }^{\circ} \mathrm{C}$ and from 0.28 to $0.24 \mathrm{~kJ} / \mathrm{mol} \mathrm{K}$ at $70{ }^{\circ} \mathrm{C}$ in the $X$ range of $0.001-0.400 \mathrm{~kg} / \mathrm{kg}$, d.b. Differential entropy represents the algebraic sum of the integral entropy at a particular hydration level, plus the change of order or disorder when new water molecules are adsorbed by the system at the same hydration level. These values correspond to the maximum and minimum differential entropy, where it is possible to observe changes in the ordering of the water molecules adsorbed in the orange peel when increasing the moisture content (RIZVI, 2005). Ning-Chuan and Xue-yi (2012) calculated the surface area of orange peels $\left(0.828 \mathrm{~m}^{2} \mathrm{~g}^{-1}\right)$ and observed a strong capacity of adsorption. In addition, orange peels contain a considerable amount of cellulose, hemicellulose and lignin, which should be relevant for further industrial applications as adsorbent material (GUPTA \& NAYAK, 2012; FOO \& HAMEED, 2012; VELÁZQUEZ-NUÑEZ et al., 2013). The influence of the orange peel composition on water adsorption and desorption should be studied to understand, with higher precision, the influence of this compounds in the mechanism of chemisorption.

The Gibbs free energy $(\Delta G, \mathrm{~kJ} / \mathrm{mol})$, calculated as a function of the moisture content, was used to correlate the differential enthalpy and entropy. Figure 2c shows similar values for experiments at 20 and 70 ㄷ $\mathrm{C}$ and in every case, lower than zero. This fact suggests that water sorption occurred in a spontaneous way. In general terms, Figs. $2 a-2 b$ showed stronger intermolecular interactions or bonding (related to the enthalpy), which would lead to a greater reduction in the freedom of configuration and hence, to a greater order of the system (related to the entropy). This relationship might allow for the application of the enthalpy-entropy compensation theory (KRUG et al., 1976a; KRUG et al., 1976b) to the orange peels, since the reaction rate should be similar for all the reactions occurring at the evaluated temperatures.

Integral thermodynamic properties of water sorption

The integral enthalpy $\left(\Delta H_{i n t^{\prime}} \mathrm{J} / \mathrm{mol}\right)$ of water sorption for orange peel was determined using the spreading pressure (Eq. (12)) by optimization of the derivate water activity from the calculated equilibrium moisture content using $\mathrm{GAB}$ model. The results obtain are shown in Figure $3 a, 5$ at 20 and 70 으, as a function of the water activity. 

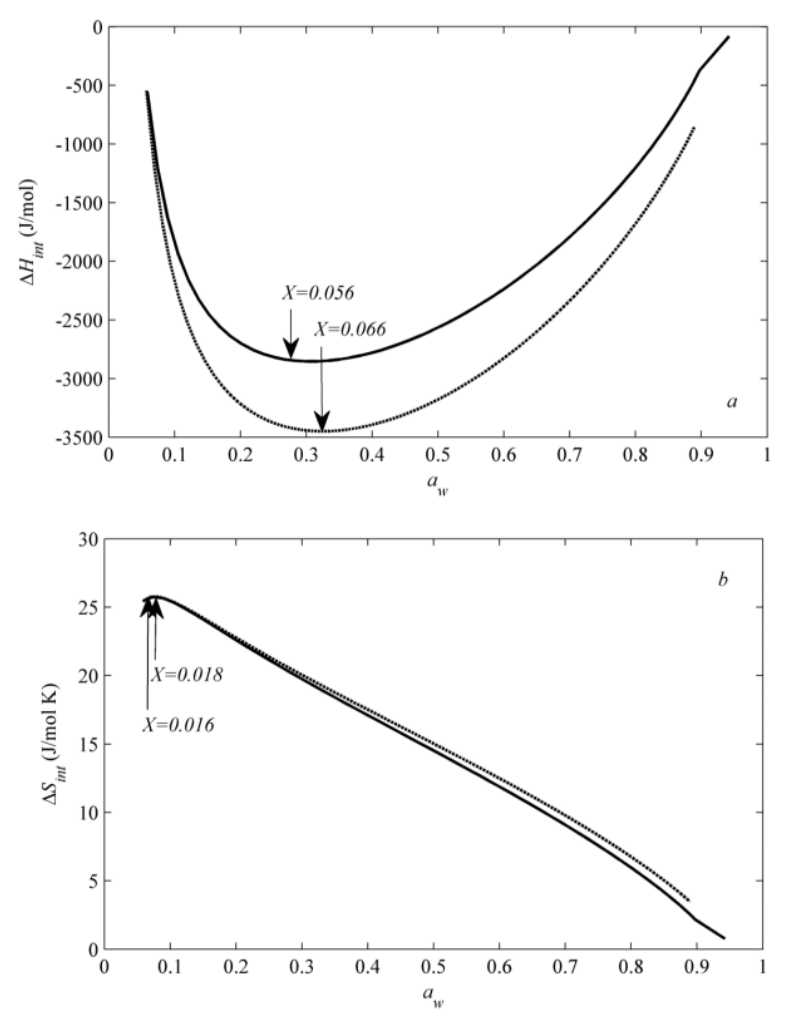

Figure 3. Integral enthalpy $(a)$ and integral entropy $(b)$ of water sorption for orange peel at $20^{\circ} \mathrm{C}(-)$ and $70^{\circ} \mathrm{C}(---)$, as a function of the water activity.

In Figure 3a, a maximum is found in the curves, which indicates the location of the bound water and the degree in which the water-solid interaction is greater than the interaction of the water molecules. In this point, the minimum integral entropy $\left(\Delta H_{i n t}\right)$ for adsorption was -2853.7 $\left(a_{w}=0.284\right)$ and $-3449.4 \quad\left(a_{w}=0.322\right) \quad J \cdot \mathrm{mol}^{-1}$ at temperatures of 20 and $70^{\circ} \mathrm{C}$, respectively. Minimum values of $\Delta H_{i n t}$ was found at the moisture content range from 0.056 to $0.066 \mathrm{~kg} / \mathrm{kg}$, d.b. being these sites the more homogeneous in terms of energy and therefore more stable to $a_{w}$ changes for orange peel produced by convective drying process. These observation were reported for Viganó et al. (2012) using different drying methods. On the other hand, at minimum values of $\Delta H_{i n t}$ the access of the water into the material can be increased. According to Syamaladevi et al. (2010), a small increase in the water content may produce a large depression of glass transition temperature due to the water plasticization effect. Intermediate moisture foods prepared by hydration may be in glassy state, while a food with an equivalent water activity prepared by dehydration may be in the rubbery state as a result of greater water content. Thus, orange peel showed a glassy state due to solubilisation of the sugars and the plasticization of the surface caused by the drying process pretreatment.

In Figure 3b, the integral entropy $\left(\Delta S_{i n t^{\prime}}\right.$ $\mathrm{J} / \mathrm{mol} \mathrm{K}$ ) that can be qualitatively interpreted in terms of the order-disorder of the adsorbed molecules (RIZVI, 2005) showed maximum values of $25.76\left(a_{w}=0.074\right)$ and $25.75\left(a_{w}=0.081\right) \mathrm{J} / \mathrm{mol} \mathrm{K}$ at temperatures of 20 and $70{ }^{\circ} \mathrm{C}$, respectively. The maximum values of $\Delta S_{i n t}$ were found in the moisture content range between 0.016 to $0.018 \mathrm{~kg} / \mathrm{kg}$, d.b. and can be considered as the zone of major energetic interaction of water molecules in the material. $\Delta S_{i n t}$ values for $a_{w}$ higher than 0.018 can be linked to the most stability or minimum integral entropy for orange peel. According to Hill et al. (1951) the minimum integral entropy can be interpreted as the required moisture content for forming a monolayer, due to the monolayer corresponds to a small number of configurations in the system. Thus, in this work, it can be assumed that the maximum stability of orange peel corresponds to the minimum integral entropy zone, as in this zone, the water molecules are well organized and less available for taking part in spoilage reactions (GONELLI et al., 2013; VIGANÓ et al., 2012).

\section{CONCLUSIONS}

Sorption isotherms for orange peel were experimentally determined at 20,30, 40, 50, 60 and $70{ }^{\circ} \mathrm{C}$, in a wide range of water activity and moisture content values. The theoretical GAB model was used adequately to represent the adsorption data and, as well as to estimate the differential and integral thermodynamic properties of water sorption at minimum and maximum temperatures. These properties were calculated by optimization as a function of both equilibrium moisture content and water activity. Differential thermodynamics properties presented high correlation with the equilibrium moisture content of orange peel, denoted a presence of a high zone of energetic interaction water molecules with material surface. Integral properties showed an equilibrium zone controlled by the enthalpy and entropy, data fundamental to the correct preservation of the product, as well providing parameters to design and optimization of the convective drying process and storage conditions 


\section{ACKNOWLEDGEMENTS}

The authors are grateful to the National Council for Scientific and Technological Development (CNPq) for the financial support.

\section{REFERENCES}

AL-MUHTASEB, A.H.; MCMINN, W.A.M.; MAGEE, T.R.A. Moisture sorption isotherm characteristics of food products: a review. Trans IChemE, v. 80 , p. 118-128, 2002.

AOAC. Offical Methods of Analysis of AOAC International. Gaithersburg, USA, Association of Analytical Chemists International AOAC, 1997.

ASAE , Psychrometric data. American Society of Agricultural Engineers ASAE, v. 1998.

BEJAR, A.K.; MIHOUBI, N.N.; KECHAOU, N. Moisture sorption isotherms - Experimental and mathematical investigations of orange (Citrus sinensis) peel and leaves. Food Chem., v. 132, p. 1728-1735, 2012.

BROVCHENKO, I. e OLEINIKOVA, A. Interfacial and confined water. Oxford, Elsevier, 2008.

BRUNAUER, S.; DEMING, L.S.; DEMING, W.E.; TROLLER, E. On the theory of van der waals adsorption of gases. Journal of the American Chemical Society, v. 62, p. 17231732, 1940.

CANO-HIGUITA, D.M.; VILLA-VÉLEZ, H.A.; TELIS-ROMERO, J.; VÁQUIRO, H.A.; TELIS, V.R.N. Influence of alternative drying aids on water sorption of spray dried mango mix powders: a thermodynamic approach. Food and Bioproducts Processing, v. 1-12, 2013.

DOIJODE, S.D. Seed Storage of Horticultural Crops. New York, Food Products Press, 2001.

DOMÍNGUEZ, I.L.; AZUARA, E.; VERNON-CARTER, E.J.; BERISTAIN, C.I. Thermodynamic analysis of the effect of water activity on the stability of macadamia nut. Journal of Food Engineering, v. 81, p. 566-571, 2007.

EIM, V.S.; ROSSELLÓ, C.; FEMENIA, A.; SIMAL, S. Moisture sorption isotherms and thermodynamic properties of carrot. International Journal of Food Engineering, v. 7, p. 1-18, 2011.

FENG, N.-C. and GOU, X.-Y. Characterization of adsorptive and mechanism on adsorption of copper, lead and zinc by modified orange peel. Transactions of Nonferrous Metals Society of China, v. 22, p. 1224-1231, 2012.

FOO, K.Y. and HAMEED, B.H. Preparation, characterization and evaluation of adsorptive properties of orange peel based activated carbon via microwave induced $\mathrm{K}_{2} \mathrm{CO}_{3}$ activation. Bioresource Technology, v. 104, p. 679-686, 2012.

GABAS, A.L.; TELIS, V.R.N.; SOBRAL, P.J.A.; TELISROMERO, J. effect of maltodextrin and arabic gum in water vapor sorption thermodynamics properties of vacuum dried pineapple pulp powder. Journal of Food Engineering, v. 82, p. 246-252, 2007.

GARAU, M.C.; SIMAL, S.; ROSSELLÓ, C.; FEMENIA, A. Effect of air-drying temperature on physico-chemical properties of dietary and antioxidant capacity of orange (Citrus aurantium v. Canoneta) by-products. Food Chemistry, v. 104, p. 1014-1024, 2007.

GARCÍA, C.F.; MOYANO, P.C.; PEDRESCHI, F. EnthalpyEntropy Compensation for Water Loss of Vegetable Tissues during Air Drying. Drying Technology, v. 26, p. 1563-1569, 2008.

GARCÍA-PÉREZ, J.V.; CÁRCEL, J.A.; CLEMENTE, G.; MULET, A. Water sorption isotherms for lemon peel at different temperatures and isosteric heats. LWT, v. 41, p. 18-25, 2008.

GHANEM, N.; MIHOUBI, D.; KECHAOU, N.; MIHOUBI, N.B. Microwave dehydration of three citrus peel cultivars: effect on water ad oil retention capacities, color, shrinkage and total phenols content. Industrial Crops and Products, v. 40, p. 167-177, 2012.

GONELLI, A.L.D.; CORRÊA, P.C.; OLIVEIRA, G.H.H.; AFONSO-JÚNIOR, P.C. Water sorption properties of coffe fruits, pulped and green coffe. LWT - Food Science and Technology, v. 50, p. 386-391, 2013.

GUPTA, V.K. and NAYAK, A. cadmium removal and recovery from aqueous solutions by novel adsorbents prepared from orange peel and $\mathrm{Fe}_{2} \mathrm{O}_{3}$ nanoparticles. Chemical Engineering Journal, v. 180, p. 81-90, 2012.

HILL, T.L.; EMMETT, P.H.; JOYNER, L.G. Calculation of thermodynamic functions of absorbed molecules from adsorption isotherms measurements: nitrogen on graphon. Journal of Chemistry Physics, v. 73, p. 51025107, 1951.

JOWITT, R.; ESCHER, F.; HALLSTOM, B.; MEFFERT, H.F.T.; SPIESS, W.E.L.; VOS, G. Physical properties methods of foods. London, Applied Science Publishers, 1987.

KRUG, R.R.; HUNTER, W.G.; GRIEGER, R.A. Enthalpyentropy compensation. 1. Some fundamental statistical problems associated with the analysis of Von't Hoff and Arrhenius data. Journal of Physical Chemistry, v. 80, p. 2335-2341, 1976a.

KRUG, R.R.; HUNTER, W.G.; GRIEGER, R.A. Enthalpyentropy compensation. 2. Separation of the chemical from the statistical effect. Journal of Physical Chemistry, v. 80 , p. $2341-2351,1976$ b.

LABUZA, T.P.; KAANANE, A.; CHEN, J.Y. Effect of temperature on the moisture sorption isotherms and 
water activity shift of two dehydrates foods. Journal of Food Science, v. 50, p. 385-389, 1985.

LIN, C.M.; SHEU, S.R.; HSU, S.C.; TSAI, Y.H. Determination of bactericidal efficacy of essential oil extracted from oragne peel on the food contect surfaces. Food Control, v. 21 , p. $1710-1715,2010$.

MAJD, K.M.; KARPARVARFARD, S.H.; FARAHNAKY, A.; JAFARPOUR, $\mathrm{H}$. Thermodynamic of water sorption of grape seed: temperature effect of sorption isotherms and thermodynamic characteristics. Food Biophysics, v. 7, p. 1-11, 2012.

MCMINN, W.A.M.; AL-MUHTASEB, A.H.; MAGEE, T.R.A. Enthalpy-entropy compensation theory in soprtion phenomena of starch materials. Journal of Food Engineering, v. 38, p. 505-510, 2005.

MRAD, N.D.; BONAZZI, C.; BOUDHRIOUA, N.; KECHAOU, N.; COURTOIS, F. Influence of sugar composition on water sorption isotherms and on glass transition in apricots. Journal of Food Engineering, v. 111, p. 403-411, 2012.

MULET, A.; GARCÍA-PASCUAL, P.; SANJUÁN, N.; GARCÍAREVERTER, J. Equilibrium isotherms and isoteric heats of morel (Morchela esculenta). Journal of Food Engineering, v. 53, p. 75-81, 2002.

NEZBEDA, I. and WEINGERL, U. A molecular-based theory for the thermodynamic properties of water. Molecular Physics, v. 99, p. 1595-1606, 2001.

NING-CHUAN, F. and XUE-YI, G. Characterization of adsorptive capacity and mechanisms on adsorption of copper, lead and zinc by modified orange peel. Transactions of Nonferrous Metals Society of China, v. 22, p. 1224-1231, 2012.

PRETTE, A.P.; ALMEIDA, F.A.C.; VILLA-VÉLEZ, H.A.; TELISROMERO, J. Thermodynamic properties of water sorption of jackfruit (Artocarpus heterophyllus Lam.) as a function of moisture content. Food Science Technology, Campinas, v. 33, p. 199-208, 2013.

RAEISSI, S.; DIAZ, S.; ESPINOSA, S.; PETERS, C.J.; BRIGNOLE, E.A. Ethane as an alternative solvent for supercritical extraction of orange peel oils. Journal of Supercritical Fluids, v. 45, p. 306-313, 2008.

REZZADORI, K.; BENEDETTI, S.; AMANTE, E.R. Proposal for the residues recovery: orange waste as raw material for new products. Food and Bioproducts Processing, v. 90, p. 606-614, 2012.

RIZVI, S.S.H. Thermodynamic Properties of Foods in Dehydration. In: RAO, M.A.; RIZVI, S.S.H.; DATTA, A.K. Engineering Properties of Foods. Boca Raton: Taylor \& Francis Group, 2005.

ROMAN, G.N.; URBICAIN, M.J.; ROTSTEIN, E. Moisture equilibrium in apples at several temperatures: experimental data and theoretical considerations. Journal of Food Science, v. 47, p. 1484-1488, 1982.

SIMAL, S.; FEMENIA, A.; CASTELL-PALOU, Á.; ROSSELLÓ, C. Water desorption thermodynamic properties of pineapple. Journal of Food Engineering, v. 80, p. 12931301, 2007.

SYAMALADEVI, R.M.; SABLANI, S.S.; TANG, J.; POWERS, J.; SWANSON, B.G. Water sorption and glass transition temperatures in red raspberry (Rubus idaeus). Thermochimica Acta, v. 503-504, p. 90-96, 2010.

TSAMI, E. Net isosteric heat of sorption in dried fruits. Journal of Food Engineering, v. 14, p. 327-335, 1991.

USDA, Citrus: world markets and trade, Washington, United States Department of Agriculture, p. 1-10 .2015.

VELÁZQUEZ-NUÑEZ, M.J.; AVILA-SOSA, R.; PALOU, E.; LÓPEZ-MALO, A. Antifugal activity of orange (Citrus sinensis var. Valencia) peel essential oil applied by direct addition or vapor contact. Food Control, v. 31, p. 1-4, 2013.

VIGANÓ, J.; AZUARA, E.; TELIS, V.R.N.; BERISTAIN, C.I.; JIMÉNEZ, M.; TELIS-ROMERO, J. Role of enthalpy and entropy in mositure sorption behavior of pineapple pulp powder produced by different drying methods. Thermochimica Acta, v. 528, p. 63-71, 2012.

VILLA-VÉLEZ, H.A.; VÁQUIRO, H.A.; BON, J.; TELISROMERO, J. Modelling thermodynamic properties of banana waste by analytical derivation of desorption isotherms. International Journal of Food Engineering, v. 8, p. 1-21, 2012.

WILHELM, N.A.; DAVID, R.; ZUO, Y. Applied surface thermodynamics. Boca Raton, CRC Press: Taylor \& Francis Group, 2011. 